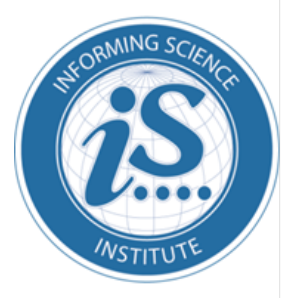

Proceedings of the Informing Science + Information Technology Education Conference

An Official Publication

of the Informing Science Institute

InformingScience.org

InformingScience.org/Publications

July 31 - August 5 2017, Ho Chi Minh City (Saigon), Vietnam

VIETNAM RUN:

\title{
AN ALTERNATIVE APPROACH TO MOBILE LEARNING
}

Brian McCauley*

Li Ping Thong

Mathews Nkhoma

Nhan Nguyen

* Corresponding author
RMIT, Ho Chi Minh, Vietnam

RMIT, Melbourne, Australia

RMIT, Ho Chi Minh, Vietnam

RMIT, Ho Chi Minh, Vietnam brian.mccauley@rmit.edu.vn

liping.thong@,rmit.edu.au

mathews.nkhoma@,rmit.edu.vn

nhan.nguyen@rmit.edu.vn

\section{ABSTRACT}

Aim/Purpose

Background

Methodology

Contribution

Findings

Recommendations for Practitioners

Recommendation for Researchers Impact on Society
How to spread an anti-littering message amongst Vietnamese youth.

We outline the design of a mobile game aimed at educating the target audience on the value of not littering.

We use key theory from the literature to inform the design of the game.

This paper outlines an approach to education that could provide value in reconceptualizing mobile learning in future. A unique mobile game, Vietnam Run, was designed and developed for the Vietnamese audience, and its game design considerations outlined. There is a lack of studies conducted in the area of mobile serious games within the context of Vietnam. This paper addresses the existing gap in the present literature from that perspective. The game design considerations outlined in this paper could be adapted and applied to the future development of similar mobile serious games in Vietnam.

Localization as a starting point increases value when a key problem and target audience has been identified. Social cognitive theory and elaboration likelihood model forms the overarching theory that defines game design to sustain player interest and engagement.

Academic theory can provide a conceptual starting point for designing educational tools.

Application of theory in real world applications lends credence and delivers measurable impact in order to demonstrate value of previous work.

It is anticipated that Vietnam Run will have value in spreading positive antilittering message within Vietnam and provide a starting point for future projects that can expand the aims of this project further.

Accepted by Executive Review by Editor Eli Cohen | Received: June 14, 2017 | Revised: June 18, 2017| Accepted: June 19, 2017.

Cite as: McCauley, B., Thong, L. P., Nkhoma, M., \& Nguyen, N. (2017). Vietnam Run: An alternative approach to mobile learning. Proceedings of the Informing Science and Information Technology Education Conference, Vietnam,pp.158168. Santa Rosa, CA: Informing Science Institute. Retrieved from http://www.informingscience.org/Publications/3773

(CC BY-NC 4.0) This article is licensed to you under a Creative Commons Attribution-NonCommercial 4.0 International License. When you copy and redistribute this paper in full or in part, you need to provide proper attribution to it to ensure that others can later locate this work (and to ensure that others do not accuse you of plagiarism). You may (and we encourage you to) adapt, remix, transform, and build upon the material for any non-commercial purposes. This license does not permit you to use this material for commercial purposes. 
Future Research The future success of the game will be analyzed through media reach, game downloads and in-game analytics in order to provide a strong conceptual basis for future work in this area.

Keywords mobile learning, serious games, Vietnam

\section{INTRODUCTION}

Cities in Vietnam are often unsanitary and visibly polluted with mostly plastic (De Koning, Crul, Wever, \& Brezet, 2015). In developing countries, the majority of citizens admit their public littering behaviors, mostly due to the already-dirty surrounding area (Al-khatib,Arafat, Daoud, \& Shwahneh, 2009). This chronic littering problem poses harmful consequences environmentally, socially and aesthetically (Ong \& Sovacool, 2012). In an effort to thwart littering behavior, the Vietnamese government issued a decree in November, 2016, imposing heavy administrative penalties on offenders who litter in public spaces. Yet, such measure has been ineffective in deterring unwarranted littering behavior, in part attributed to poor environmental awareness, a shortage of dustbin facilities, and a lack of surveillance to catch offenders in the act of littering ("Fines fail to deter HCM City litter bugs", 2017). As such, it is imperative to consider alternative measures that could feasibly increase the public's environmental awareness to affect positive change in the Vietnamese community.

Past studies have indicated mobile games as a viable pedagogical tool to embed both learning and playing within mobile environments (Attewell \& Savill Smith, 2005) to enable different learning experiences such as collaborative learning (Bull et al., 2005), vocabulary learning (Sandberg,Maris, \&Hoogendoorn, 2014) and gamification (Su \& Cheng, 2015). It is worth noting that the Vietnamese population are enthusiastic casual gamers that primarily use games on mobile devices (phones, tablets) as their source of entertainment. In 2014, 48\% (350 million) of app downloads in Vietnam were games (Appota Corp, 2014). Appota's 2016 report indicated that games were the top category $(40 \%)$ for downloaded apps in March 2016 ("Vietnam Mobile Report Q3", 2016). Yet, despite the immense popularity of mobile games in Vietnam, its use as a potentially effective platform to affect positive behavioral change has not been adequately investigated in the present literature. This study seeks to investigate the feasibility of using mobile games to positively affect littering behavior in Vietnam. In doing so, Vietnam Run - a2D platform game targeted for mobile devices - was designed and developed with the aim of reinforcing players' environmental awareness and curbing littering habits. The game was designed and developed over a timeline of 6 months and will be marketed and tested to a wide user-base in Vietnam. This paper will elaborate on the overarching pedagogical goals and game design rationale of Vietnam Run.

\section{Serious Games and Serious Games Promoting EnVironmental IsSUES}

Serious games are regarded as games designed with specific purposes other than entertainment (Susi, Johannesson, \& Backlund, 2007). Unlike its closely related concept (educational games), serious games are designed to look more alike to commercial games (Stege, Van Lankveld, \& Spronck, 2011). Due to its ability to motivate and improve students' concentration, serious games in education is believed to benefit the learning process (Virvou, Katsionis, \& Manos, 2005). The use of games within the context of education created a shift towards a new learning paradigm, in which the traditional principles of teaching and learning, often presented to learners as chunks of knowledge, is now substituted with the use of serious games to simulate experiences, create virtual apprenticeships (de Freitas \&Maharg, 2011), or discover new ideas and engage in problem-based learning (Kiili, 2005).

Serious games have been utilized not only to improve knowledge and skills of gamers but also to initiate behavior change. This approach has been widely applied in health sector and found to generate a positive result (Baranowski, Buday, Thompson, \& Baranowski, 2008; Baranowski et al., 2011). For instance, players of a serious game promoting healthy lifestyle indeed perform actions of healthier living during the playing period (Lin, Mamykina, Lindtner, Delajoux, \& Strub, 2006). Similar posi- 
tive results are also recorded for games promoting environmental friendly actions, such as energy saving (Gustafsson, Katzeff, \& Bang. 2009; Orland et al., 2014). The changes in physical activities are created since a lot of these games involve goal setting and goal review, two of the basic components of behavioral changes(Thompson et al., 2007).

Given the proven benefits of serious games in other sectors, utilizing this approach to raise the public's awareness about the environment has attracted the interest of scholars. Environmental serious games were welcomed by gamers in a pilot test conducted in Thailand (Yongyuth, Prada, Nakasone, Kawtrakul, \& Prendinger 2010). In a field test, the game received positive feedback amongst a group of teachers, who believed the game and its procedure can successfully promote environmental literacy (Arslan, Moseley, \& Cigdemoglu, 2011). Hildmann and Hirsch (2008) reported a shift in attitude toward protecting the environment after children play serious games about the environment. Although addressing environmental sustainability is one of the recurring theme in serious games (Tanenbaum, Antle, \& Robinson, 2013), there is little evidence to indicate a behavioral changes in this sector, especially in developing countries.

In Vietnam, there are currently no games designed for such purpose. Little research has been conducted on digital gaming in Vietnam (McCauley, Nguyen, \& McDonald, 2016). In one study, McDonald (2017) examined the role of games in influencing learning outcomes among Vietnamese youth. Through playing a game (The Coffee Shop), players in McDonald's (2017) study were tasked in managing the stock for a coffee shop to maximize profits. Playing the game resulted in learning through improved business skill knowledge, enhanced critical thinking, and problem solving. Importantly, it was found that "students generally enjoyed the experience and asked to play the game again seeking to better their outcomes and, in the competitive spirit of this age-group, they wished to outscore and outperform their peers" (McDonald, 2017, p. 89).

A report by NewZoo (2017) estimates that, of 45 million smartphone owners in Vietnam, 30 million play mobile games with approximately 10 million aged between $10-20$. South East Asia is a mobile first gaming region where players primarily play on mobile and in Vietnam local games such as ứuÂm-BảnCáiBang perform well on app charts (NewZoo, 2017). Mobile serious games provide added mobility towards the game-playing experience, enabling users to play as they move about within the real-world (Stone, 2005).The unique characteristics of mobile learning supports various pedagogies and learning experiences for learners in both formal and informal environments (Stanton \& Ophoff, 2013). Mobile devices free learning from the situated experience due to its ubiquitous nature (Stanton \& Ophoff, 2013). Yet traditional mobile learning may not always be the best solution for every educational objective. For example, intention to adopt mobile learning is determined by a complex set of interrelated motivational, perceptual, and belief factors and as a result not all students may be suited to this learning mode (Mac Callum\& Jeffrey, 2014). Traditional mobile learning may not always be successfully adopted by students, yet games remain one of the top uses for mobile devices (Tabor, 2016). In a study of 194 middle schoolers, video games were identified as the most preferred activity, regardless of personality type, academic performance, or technological proficiency (Colvin-Sterling, 2016). To be an effective game, a sound understanding of the game audience and their motivation is necessary (Lallie, 2015). In using a traditional learning app, students are motivated to learn when they can satisfy their need for competence, overcome challenges, have choices, or have an interest in the app (Shroff \& Keyes, 2017). These factors have previously been found to drive motivation and determine choice in mobile gaming (McCauley, 2014) and engender outcomes such as learning, health, and social change (Peng, Lee, \&Heeter, 2010).

Vietnam Run is a mobile game developed with the intention of educating Vietnamese youth on the importance of anti-littering in conjunction with Việt Nam SạchvàXanh (Vietnam Clean \& Green). The partnership with Vietnam Clean \& Green is essential, as credible organizations could serve as useful distribution channels to games about their related causes, thus reaching a wider audience base, gaining traction and exponentially increase its impact (Swain, 2007). Vietnam Clean \& Green is a local NGO with a mission to reduce littering in Vietnam and to bring about momentous societal 
change through raising public awareness about the negative impacts of littering and highlighting the importance of individual responsibility (Vietnam Clean \& Green, 2017). The game incorporates existing brand assets of Vietnam Clean \& Green, the Green Turtle Army (Figure 1), for ease of brand recognition and ensuring that a consistent message could be utilized as part of a larger campaign. Vietnam Clean \& Green currently organizes Earth annual Day clean up events with local volunteers and schoolchildren throughout Vietnam (Figure 2).

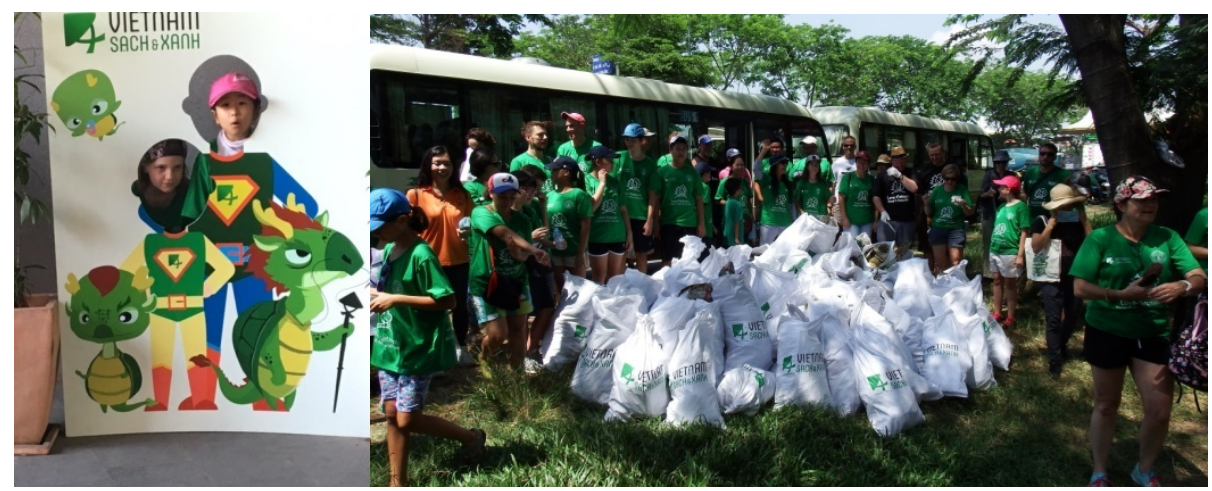

Figure 1.The Green Turtle Army

Figure 2. Annual Earth Day cleanup

\section{VIETNAM RUN}

Vietnam Run is a runner game, which is a genre of platform games in which the player character is continuously moving forward with simple gameplay that makes it appealing for mobile platforms (de Medeiros \& de Medeiros, 2014). Famous and successful commercial examples include Temple Run (2011) and Mario Run (2016). Whilst there has been limited games designed for social change that falls into the platform game genre, this genre was selected for Vietnam Run as it is an established mobile gaming mainstay with an appeal to gamers of all levels due to the often simplistic and addictive gameplay. The development and implementation of Vietnam Run serve two purposes. First, the game is intended to deliver a key message aimed directly at Vietnamese youths that Vietnam is beautiful; that everyone should all do their part in not littering. Secondly, the game is designed to support Vietnam Clean \& Green's efforts to educate younger Vietnamese in the importance of not littering through raising awareness in the media and becoming a central component of in-school education campaigns.

The choice of platform frames the experience of playing games, as each platform offers different advantages in terms of graphic quality, screen size, portability, input controls, ease of use, and choice of titles (Hutchison, 2007). The choice of mobile as our platform creates a starting point in terms of concept and design. With both Android and IOs popular, Vietnam Run will be released on both mobile operating systems to ensure maximum reach.

\section{GAME DESIGN}

The social cognitive theory and elaboration likelihood model serves as the overarching model of learning for behavioral changes through games (Baranowski et al., 2008). More specifically, in encouraging positive behavior change, Petty and Cacioppo's (2012) elaboration likelihood model proposed that sustaining a person's attention is crucial in enabling the individual to effectively process the informational message. As such, to reinforce our key message of anti-littering and increase player's' attention span, we incorporated two key elements to enable an immersive and engaging gameplaying experience.

The first key element is the localization of the game concept, content and design to generate interest of targeted users (Vietnamese users) in playing the game. Localization of video games is where aspects of a game, potentially including language, imagery, narrative, game mechanics, and overall de- 
sign aesthetic, are modified to accommodate regional markets (Carlson \& Corliss, 2011). In the context of Vietnam Run, five locations within Vietnam that have deep resonance were selected as visual reference for level design, due to factors including uniqueness, beauty, or population. Sapa (Figure 3) is a small town in Northwestern Vietnam that remains a major tourist attraction; beautiful terraced hillsides represent a distinct and unique feature of Vietnam. Halong Bay is a popular tourist destination and designated World Heritage site, characterized by thousands of iconic limestone islands that are embedded within the level through players being required to jump from island to island. The Mekong Delta in Southwestern Vietnam is a famous tourist attraction with approximately 18 million inhabitants, characterized by rivers, islands, boats, and floating markets. Hanoi as the capital of Vietnam and second largest city with a population of approximately 8 million hosts the most cultural sites in Vietnam, and we include distinct landmarks and icons from Hanoi such as the Old Quarter and HoanKiem Lake. Ho Chi Minh City (Figure 4) with a population estimated in excess of 10 million features iconic landmarks such as Bitexeco Tower, Independence Palace, and Notre Dame Cathedral. Without situating the game in recognizably Vietnamese locations we lose what Squire (2008) argues is an important cultural aspect of learning in games: ideological worlds. Squire's (2008) idea of ideological worlds is of gaming environments with values, visions, and ideas in which players can perform and reflect on meanings. Locating the game in locations with relevance to the target audience enhances the values and ideas embedded within the game.

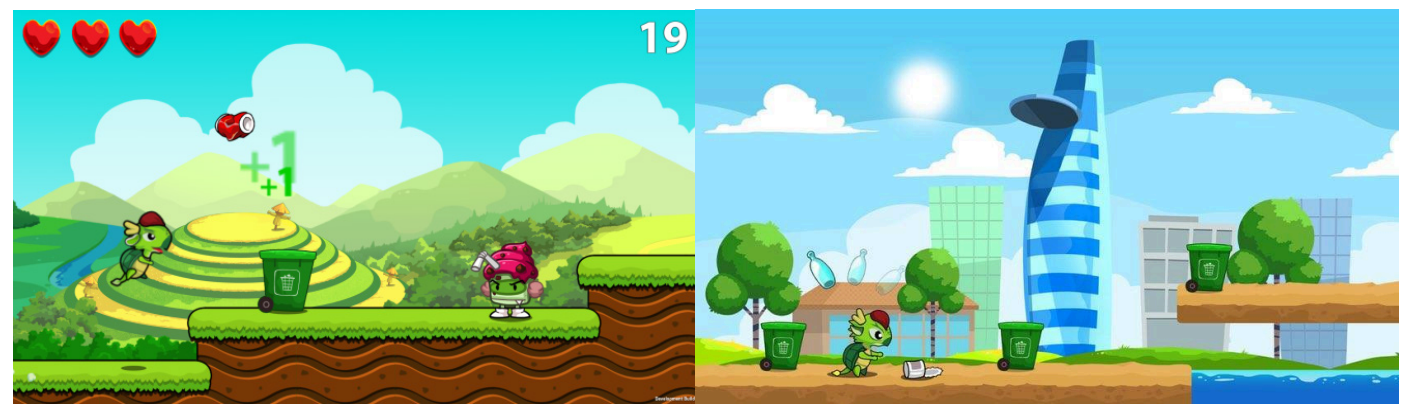

Figure 3: SapaFigure 4: Ho Chi Minh City

The second element of the design was to deliver the key message. The first stage of this was to embed the message into the gameplay itself. Traditionally platform or runner games allow players to collect elements such as rings, coins, or valuables in order to earn points as they progress. Similar games such as Mario Run or Sky Dancer (2017) allow players to collect coins as they run. In this case, we embedded the concept of picking up litter to earn points by reinforcing picking up litter as a positive experience. Litter bins are situated throughout each level and as the players move over litter it is automatically thrown in a litter bin visibly earning the player's a reward through extra points. At surface level, this graphical representation of a simple animation of litter being thrown into the bin may appear to be a simplistic reward system, but, in parallel, a deeper form of behavioral depiction and mimicry is also taking place. As players immerse themselves as imaginary roles in games, Peng et al. (2010) argued that the player and avatar identities gradually converge - players identify with the character strongly and are emotionally invested on the character's successes and failures. Thus, from a motivational standpoint, the player shares similar goals as the character. Given that games add an element fun (Gee, 2003; Prensky, 2007), this form of intrinsic motivation increases behavior change through improved motivation (Baranowski et al., 2008; Ryan, Rigby, \& Przybylski, 2006). From an interaction standpoint, procedural rhetoric was taken into deep consideration throughout the different iterations of game design, which encompasses the idea that fact delivery is not the basis of behavioral change, but rather the learned behavior lies within a set of interactive processes and activities encountered by users during gameplay (Tanenbaum et al., 2013).

Players play video games because they are fun and enjoyable (Gee, 2003; Prensky, 2007; Przybylski, Rigby, \& Ryan, 2010). The key elements of mobile game design relevant to enjoyment, and subsequently continued play, consist of design aesthetics, novelty, and challenge (Merikivi, Tuunainen, \& 
Nguyen, 2017). To deliver our key message successfully we need to ensure that Vietnam Run is an enjoyable experience that is simple and accessible to all players. Throughout the development process the game has been play-tested to ensure we provide a novel experience. Each location within the game will have a different level of difficulty based on speed, obstacles, enemies, and locations of litter ranging from Sapa (easiest) through Ha Long Bay, Mekong Delta, Hanoi, and Ho Chi Minh (most difficult). To ensure a balanced challenge each run itself will have three difficulty levels to ensure players can choose an appropriate level of personal challenge. More casual players can enjoy a pleasant experience on the easier setting while more skilled hardcore players can choose to challenge themselves on higher levels of difficulty. Balance is key here, as games that underwhelm or overwhelm the cognitive resources of players can lead to a negative experience that will interrupt the learning process (Turkay, Hoffman, Kinzer, Chantes, \&Vicari, 2014).

Playtesting is necessary to improve the overall experience before any official release (de Medeiros \& de Medeiros, 2014) and we will be conducting two levels of playtesting to ensure optimal design. Focus groups will be conducted among the key target audience of Vietnamese youth aged between 8 and 18 to examine their play experience and subsequent opinions. To complement this approach, we have identified several experts on gaming in industry and academia who will evaluate the game using Korhonen and Koivisto's (2006) established scale of playability heuristics for mobile games to test usability, mobility, and playability. Results from both groups will allow for optimization of the play experience pre-launch.

\section{Việt Nam thật đẹp, chúng em cùng chung sức giữ gìn}

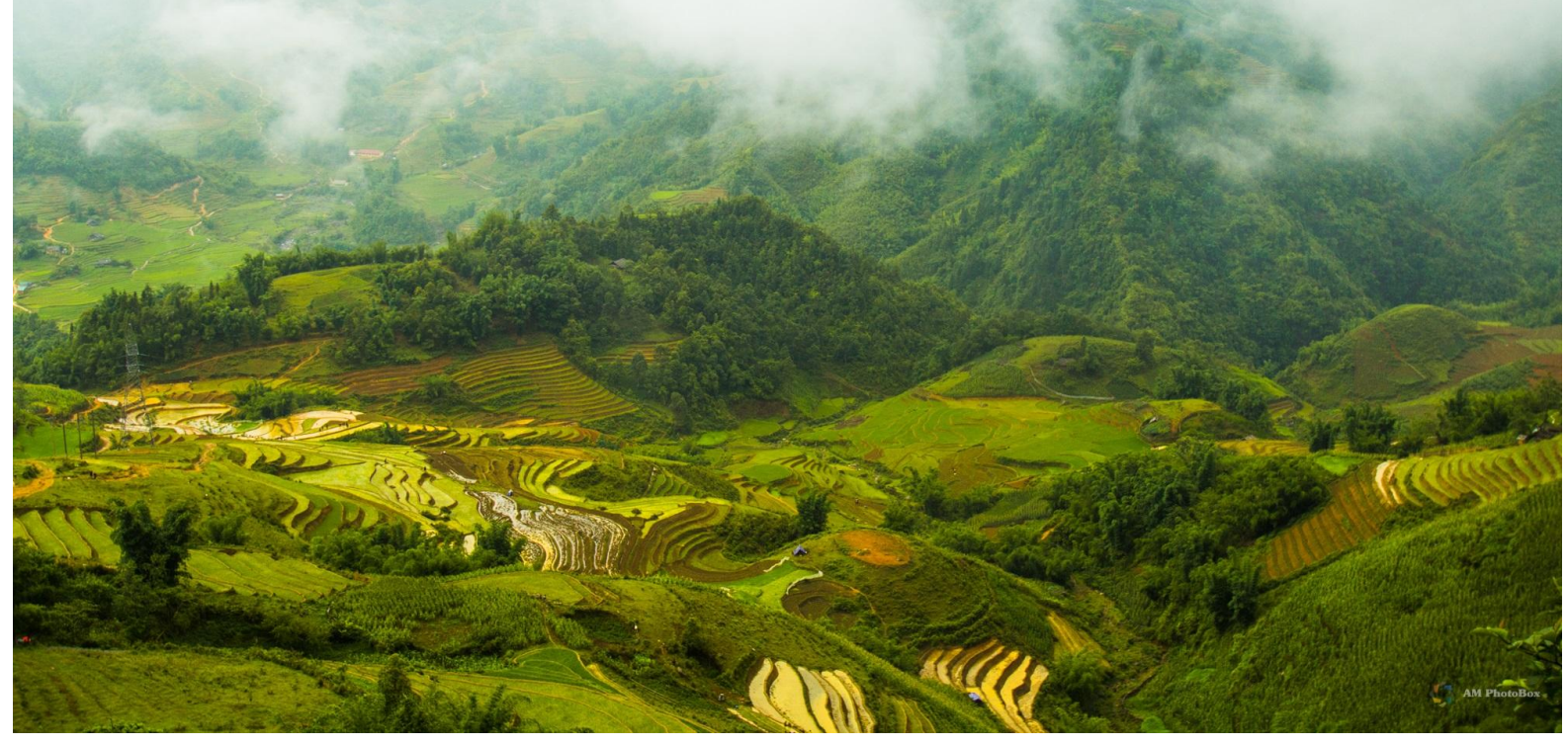

Figure 5: Vietnam is beautiful let's keep it that way

Traditionally most mobile games generate income through three methods - through app purchase, ingame revenue, or in-game purchases. As this project is a non-profit game aimed at Vietnamese youth, these elements are not part of our game design. Instead, a series of messages will appear at the completion of each level. These messages will follow two key themes. A scenic image of Vietnam with a variation on the message that 'Vietnam is Beautiful' will aim to instil a sense of national pride in our target audience (Figure 5). The second theme will showcase the work of volunteers from Vietnam 
Clean and Green collecting litter on Earth Day with an emphasis on how we can all do our part (Figure 6). Both messages will incorporate a variety of images and text to allow for the message to remain interesting and potentially relevant.

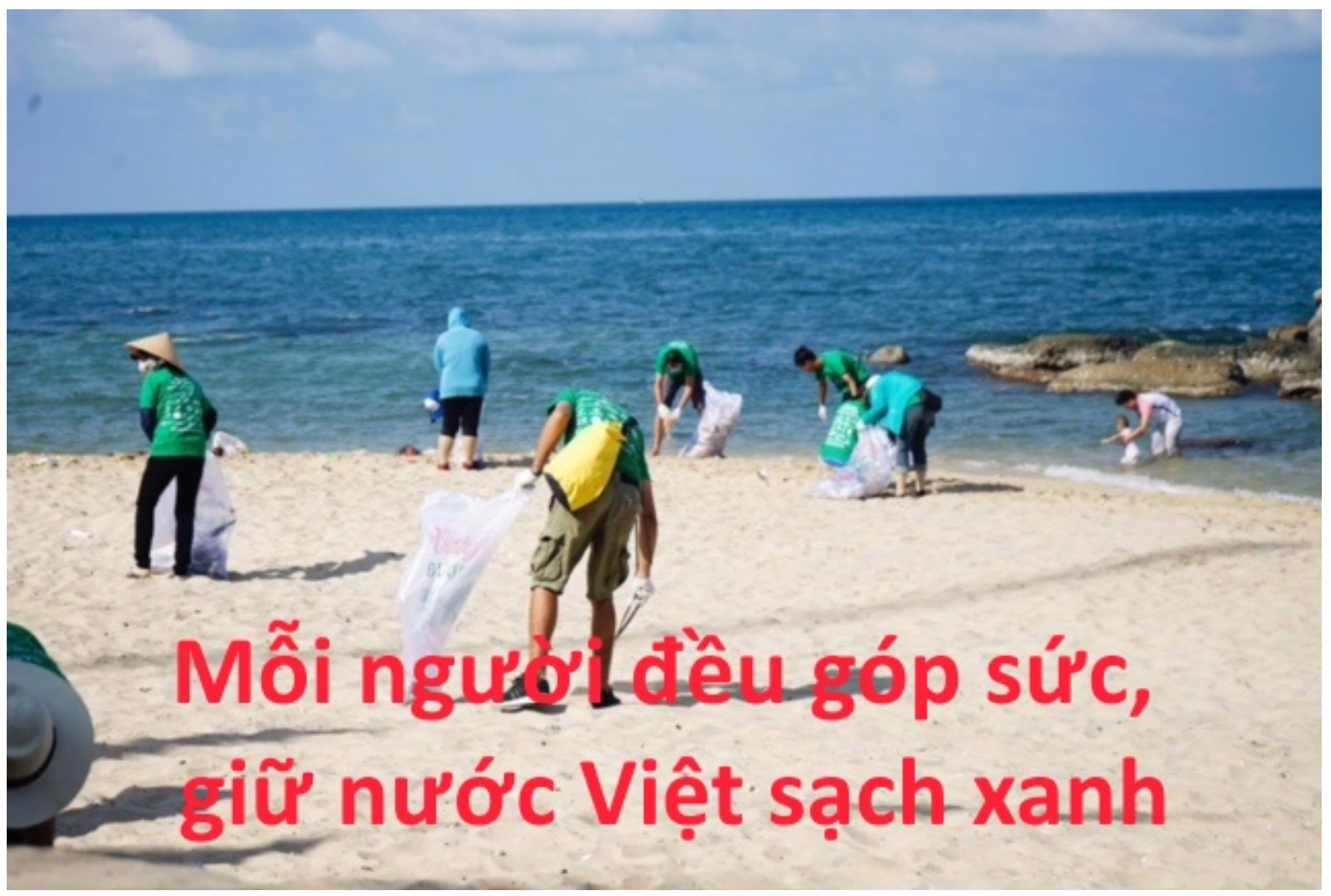

Figure 6: We all have to work together to keep Vietnam clean

\section{CONCLUSION AND IMPLiCATIONS OF THE PROJECT}

This project is aimed at supporting environmental and anti-littering education in a variety of ways.

The first and most obvious way is through delivering an anti-littering message through playing of the game itself. Through incorporating refined game design techniques, we hope the game will have a lot of replay value to deliver the key message. We also hope that competition and the elements of localization will allow for recommendations from players to spread the message further.

As part of an in school educational program delivered by Vietnam Clean and Green the game will allow for school children to become more interested and as a result, more aware of the negative impact of littering. A PC based version will be created and placed on Vietnam Clean \& Green's official website so that those without access to mobile devices can also play the game.

In many places around the world acceptance of technology in education can be slow, often due to budgetary constraints (Schofield, 2014). It is the duty of both universities and government to utilize the potential of new media in education with both stronger support and more incentives needed (Lanyi, 2011). Vietnam Run has been primarily designed as a fun vehicle to deliver an important key educational message. However the potential success of Vietnam Run, demonstrated through game downloads, research outputs, and media exposure, can also create future opportunities for advancing the use of educational mobile technologies as well as environmental campaigns throughout Vietnam in future.

Hutchison (2007) argues that teachers can incorporate the video games children play into the classroom as a part of their learning journey. Vietnam Run represents a starting point for this process in 
Vietnam. This project, and resulting applied research pertaining to the outcomes, will inform pursuit of funding to expand the scope of the Vietnam Clean \& Green and environmental education with Vietnam. We hope that Vietnam Run can eventually lead to a more educated and informed population and a cleaner, more beautiful Vietnam.

\section{REFERENCES}

Al-Khatib, I. A., Arafat, H. A., Daoud, R., \&Shwahneh, H. (2009). Enhanced solid waste management by understanding the effects of gender, income, marital status, and religious convictions on attitudes and practices related to street littering in Nablus-Palestinian territory. Waste Management, 29(1), 449-455.

Appota Corp. (2014), Insights and guide to Vietnam online mobile game market.Slideshare. Retrieved on 21 May 2017 fromhttp://www.slideshare.net/appota/vietnam-online-mobile-game-market-insights-and-guide

Attewell, J., \&Savill-Smith, C. (Eds.). (2005). Mobile learning anytime everywhere: A book of papers from MLEARN 2004. Learning and Skills Development Agency.

Arslan, H. O., Moseley, C., \&Cigdemoglu, C. (2011).Taking attention on environmental issues by an attractive educational game: Enviropoly. Procedia-Social and Behavioral Sciences, 28, 801-806.

Baranowski, T., Baranowski, J., Thompson, D., Buday, R., Jago, R., Griffith, M. J., ...\& Watson, K. B. (2011). Video game play, child diet, and physical activity behavior change: A randomized clinical trial. American Journal of Preventive Medicine, 40(1), 33-38.

Baranowski, T., Buday, R., Thompson, D. I., \&Baranowski, J. (2008).Playing for real: Video games and stories for health-related behavior change. American Journal of Preventive Medicine, 34(1), 74-82.

Bull, S., Bridgefoot, L., Corlett, D., Kiddie, P., Marianczak, T., Mistry, C., ...\& Williams, D. (2005). Interactive Logbook: The development of an application to enhance and facilitate collaborative working within groups in higher education.In J. Attewell\& C. Savil-Smith (Eds.), Mobilelearning anytimeeverywhere(pp. 39-42). London: Learning and Skills Development Agency.

Carlson, R., \& Corliss, J. (2011).Imagined commodities: Video game localization and mythologies of cultural difference.Games and Culture, 6(1), 61-82.

Colvin-Sterling, S. (2016). The correlation between temperament, technology preference, and proficiency in middle school students.Journal of Information Technology Education: Research, 15, 1-18. Retrieved from https://www.informingscience.org/Publications/2333

de Freitas, S., \&Maharg, P. (Eds.). (2011). Digital games and learning. London: Bloomsbury Publishing.

De Koning, J. I. J. C., Crul, M. R. M., Wever, R., \&Brezet, J. C. (2015). Sustainable consumption in Vietnam: An explorative study among the urban middle class. International Journal of Consumer Studies, 39(6), 608-618.

de Medeiros, R. J. V., \& de Medeiros, T. F. V. (2014, November). Procedural level balancing in runner games. In Computer Games and Digital Entertainment (SBGAMES), 2014 Brazilian Symposium on (pp. 109-114). IEEE.

Fines fail to deter HCM City litter bugs. (2017, May 5) Dan Tri International. Retrieved from http://dtinews.vn/en/news/021/50731/ fines-fail-to-deter-hcm-city-litter-bugs.html

Gee, J. P. (2003). What video games have to teach us about learning and literacy.Computers in Entertainment (CIE), $1(1), 20-20$.

Gustafsson, A., Katzeff, C., \& Bang, M. (2009).Evaluation of a pervasive game for domestic energy engagement among teenagers. Computers in Entertainment (CIE), 7(4), 54.

Hildmann, H., \& Hirsch, B. (2008). Raising awareness for environmental issues through mobile device based serious games. 4th Microsoft Academic Days, Berlin, Germany.

Hutchison, D. (2007). Video games and the pedagogy of place.The Social Studies, 98(1), 35-40.

Korhonen, H., \&Koivisto, E. M. (2006, September).Playability heuristics for mobile games.In Proceedings of the 8th conference on Human-computer interaction with mobile devices and services (pp. 9-16).ACM.

Kiili, K. (2005) Digital game-based learning: Towards an experiential gaming model.The Internet and Higher Education, 8(1), 13-24. 
McCauley, Thong, Nkhoma, \& Nguyen

Lallie, H. S. (2015). Geospatial crypto reconnaissance: A campus self-discovery game. Interdisciplinary Journal of eSkills and Lifelong Learning, 11, 1-10. Retrieved from https://www.informingscience.org/Publications/2107

Lanyi, C. S. (2011). Developing Serious Games for 12-16 Year Old Students.In Proceedings of the 2011 Informing Science \& IT Education Conference, Novi Sad, Serbia.

Lin, J. J., Mamykina, L., Lindtner, S., Delajoux, G., \&Strub, H. B. (2006, September).Fish'n'Steps: Encouraging physical activity with an interactive computer game. In International Conference on Ubiquitous Computing (pp. 261-278).Springer Berlin Heidelberg.

Mac Callum, K., \& Jeffrey, L. (2014).Comparing the role of ICT literacy and anxiety in the adoption of mobile learning.Computers in Human Bebavior, 39, 8-19.

McCauley, B. (2014). Intrinsic motivations of mobility, play and enjoyment: The smartphone game experience.(Doctoral Dissertation).Retrieved from RMIT Research Repository.

McCauley, B., Nguyen, N., \& McDonald, M. (2016).Understanding the motivations of Vietnamese millennial mobile gamers: A pilot study.InHandbook on Emerging Trends in Business, Economics and Management 15-16 October pp.1-8.

McDonald, S. D. (2017). Enhanced critical thinking skills through problem-solving games in secondary schools.Interdisciplinary Journal of e-Skills and Lifelong Learning, 13, 79-96. Retrieved from http://www.informingscience.org/Publications/3711

Merikivi, J., Tuunainen, V., \& Nguyen, D. (2017). What makes continued mobile gaming enjoyable? Computers in Human Behavior, 68, 411-421.

NewZoo. (2017, Jan 11) NewZoo and GMGC release the mobile games whitebook for 2017. Retrieved from https://newzoo.com/insights/trend-reports/newzoo-and-gmgc-release-the-mobile-games-whitebook-for$\underline{2017 /}$

Ong, I. B. L., \&Sovacool, B. K. (2012).A comparative study of littering and waste in Singapore and Japan.Resources, Conservation and Recycling, 61, 35-42.

Orland, B., Ram, N., Lang, D., Houser, K., Kling, N., \&Coccia, M. (2014).Saving energy in an office environment: A serious game intervention. Energy and Buildings, 74, 43-52.

Peng, W., Lee, M., \&Heeter, C. (2010).The effects of a serious game on role-taking and willingness to help.Journal of Communication, 60(4), 723-742.

Petty, R., \&Cacioppo, J. (2012).Communication and persuasion: Central and peripheral routes to attitude change. Springer Science \& Business Media.

Prensky, M. (2007).Digital game-based learning. Minnesota: Paragon House.

Przybylski, A. K., Rigby, C. S., \& Ryan, R. M. (2010).A motivational model of video game engagement.Review of General Psychology, 14(2), 154.

Ryan, R. M., Rigby, C. S., \&Przybylski, A. (2006). The motivational pull of video games: A self-determination theory approach. Motivation and Emotion, 30(4), 344-360.

Sandberg, J., Maris, M., \&Hoogendoorn, P. (2014).The added value of a gaming context and intelligent adaptation for a mobile learning application for vocabulary learning. Computers \& Education, 76, 119-130.

Schofield, D. (2014). A virtual education: guidelines for using games technology. Journal of Information Technology Education: Innovations in Practice, 13, 25-43. Retrieved from https://www.informingscience.org/Publications/1964

Shroff, R. H., \&Keyes, C. J. (2017). A proposed framework to understand the intrinsic motivation factors on university students' behavioral intention to use a mobile application for learning. Journal of Information Technology Education: Research, 16, 143-168. Retrieved from https://www.informingscience.org/Publications/3694

Squire, K. (2008). Open-ended video games: A model for developing learning for the interactive age. In K. Salen (Ed.), The ecology of games: Connecting youth, games, and learning (pp. 167-198). Cambridge, MA: MIT Press. 
Vietnam Run: An Alternative Approach to Mobile Learning

Stanton, G., \&Ophoff, J. (2013).Towards a method for mobile learning design.Issues in Informing Science \& Information Technology, 10, 501-523. Retrieved from https://www.informingscience.org/Publications/1825?Source

Stege, L., Van Lankveld, G., \&Spronck, P. (2011). Serious games in education. International Journal of Computer Science in Sport, 10(1), 1-9.

Stone, B. (2005). Serious gaming.Defense Management Journal, 31, 142-144.

Su, C. H., \& Cheng, C. H. (2015).A mobile gamification learning system for improving the learning motivation and achievements.Journal of Computer Assisted Learning, 31(3), 268-286.

Susi, T., Johannesson, M., \&Backlund, P. (2007).Serious games: An overview.(IKI Technical Reports).Skövde. Retrieved from http://urn.kb.se/resolve?urn=urn:nbn:se:his:diva-1279

Swain, C. (2007, September). Designing games to effect social change. In Proceedings of DiGRA 2007 Conference, Situated Play (pp. 24-28).

Tabor, S. W. (2016).Making mobile learning work: Student perceptions and implementation factors.Journal of Information Technology Education: Innovations in Practice, 15, 75-98. Retrieved from https://www.informingscience.org/Publications/3524

Tanenbaum, J. G., Antle, A. N., \& Robinson, J. (2013, April). Three perspectives on behavior change for serious games. In Proceedings of the SIGCHI Conference on Human Factors in Computing Systems (pp. 3389-3392).ACM.

Thompson, D., Baranowski, T., Buday, R., Baranowski, J., Juliano, M., Frazior, M., ...\&Jago, R. (2007). In pursuit of change: Youth response to intensive goal setting embedded in a serious video game. Journal of Diabetes Science and Technology, 1(6), 907-917.

Turkay, S., Hoffman, D., Kinzer, C. K., Chantes, P., \&Vicari, C. (2014). Toward understanding the potential of games for learning: Learning theory, game design characteristics, and situating video games in classrooms. Computers in the Schools, 31(1-2), 2-22.

Vietnam Clean \& Green. (2017). Welcome to Vietnam Clean and Green. Retrieved from http://vietnamsachvaxanh.org/

Vietnam Mobile Report Q3 - An overview of trends and insights (2016) Retrieved from Appota Website:https://appota.com/uploads/report/Report Q3.pdf

Virvou, M., Katsionis, G., \& Manos, K. (2005). Combining software games with education: Evaluation of its educational effectiveness. Educational Technology \& Society, 8(2), 54-65.

Yongyuth, P., Prada, R., Nakasone, A., Kawtrakul, A., \& Prendinger, H. (2010, October). AgriVillage: 3D multilanguage internet game for fostering agriculture environmental awareness. In Proceedings of the International Conference on Management of Emergent Digital EcoSystems (pp. 145-152). ACM.

\section{BIOGRAPHIES}



Dr. Brian McCauley is a lecturer in Professional Communications at RMIT University Vietnam. He completed his PhD in Marketing Communications at RMIT Melbourne focusing on the intrinsic motivations of play of smartphone games. His research interests focus on digital behavior with a special interest in social media and digital gaming. He is currently leading several projects focusing on understanding social media and digital gaming culture in Vietnam with a view to producing impact through outputs such as the Vietnam Run. 




tion on related projects.



Dr. Mathews Z. Nkhoma is Associate professor at RMIT University Vietnam. He holds a PhD in Information Security from University of East London, England. His major research topics are information systems security, information security investment model, ethical hacking, network defense, network security management and forensic computing. Mathews has international experience in teaching- leading Information systems and computer forensics courses in Africa, Europe and the Middle East.

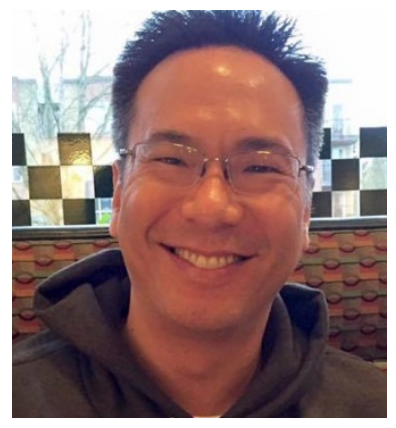

Nhan Nguyen, born in the USA to Vietnamese parents, is currently the School Manager at RMIT University Vietnam (RMIT) and has held a variety of positions at RMIT including: Program Manager, Lecturer, Course Leader and Senior Lecturer. Prior to joining RMIT in 2003, Nhan was an Internet entrepreneur having started companies in website development and search engine optimization. Nhan is the founder of Vietnam Clean and Green, which focuses on anti-littering in Vietnam. One of the campaigns being developed by Vietnam Clean and Green is the Green Turtle Army, which targets primary and elementary school students. The Vietnam Run game is a very exciting part of this campaign as it will teach children about the negative impacts of littering in a fun and interactive manner. 